\title{
ECONOMICS
}

\section{OCCUPATIONAL ATTAINMENT AND IMMIGRANT ECONOMIC PROGRESS IN AUSTRALIA}

\section{By}

Barry R. Chiswick

University of Illinois at Chicago

$\&$

IZA-Institute for the Study of Labor

and

Paul W. Miller

University of Western Australia

DISCUSSION PAPER 08.03 


\title{
OCCUPATIONAL ATTAINMENT AND IMMIGRANT ECONOMIC PROGRESS IN AUSTRALIA
}

\author{
by \\ Barry R. Chiswick \\ Department of Economics \\ University of Illinois at Chicago \\ $\&$ \\ IZA-Institute for the Study of Labor \\ and \\ Paul W. Miller \\ Business School \\ University of Western Australia
}

\begin{abstract}
Using data from the 2001 Australian Census of Population and Housing, on adult men in full-time employment, this paper augments a conventional human capital earnings function with information on occupations. It also estimates models of occupational attainment. The results from both the earnings function and model of occupational attainment indicate that the limited international transferability of human capital skills results in immigrants entering into relatively low status occupations when they first enter the Australian labour market. Comparison with similar research for the US suggests that the different immigrant selection regimes (primarily family reunion in the US, skill-based immigration in Australia) do not impact on the negative association between occupational status and pre-immigration labour market experience. (115 words)
\end{abstract}

JEL Codes: J240, J310, J 620, F22

* We thank Derby Voon for research assistance and two anonymous referees for helpful comments. Chiswick acknowledges research support from the Institute of Government and Public Affairs, University of Illinois and the Smith Richardson Foundation. Miller acknowledges financial assistance from the Australian Research Council. 


\section{OCCUPATIONAL ATTAINMENT AND IMMIGRANT ECONOMIC PROGRESS IN AUSTRALIA}

\section{Introduction}

Immigrants' labour market outcomes are generally discussed around three key concepts - the less-than-perfect international transferability of the human capital skills they acquired in their country of origin, the positive selectivity of immigrants for labour market success, especially economic immigrants, and their relatively rapid economic progress in the destination country. ${ }^{1}$ The less-than-perfect international transferability of human capital skills results in immigrants being at an economic disadvantage during their first year in the destination country. Immigrants' rapid economic progress, particularly in the immediate post-arrival period, results in a narrowing of this gap and, especially for economic immigrants, can result in a "catch-up" of their economic position compared to that of their native-born counterparts (Chiswick, 1978). This catch-up will occur when the effects of positive selection more than off-set the lingering effects of imperfect skill transferability and any discrimination against immigrants. However, after three decades of intensive research, understanding of the process of immigrant labour market adjustment that gives rise to these patterns is still far from complete.

In a recent study, using data on adult men in the United States, Chiswick and Miller (2007) argue that insights into the labour market adjustment of immigrants can be gained through estimation of earnings equations that take account of occupational status. ${ }^{2}$ Equations that also include controls for occupation show the role that occupation has as an intermediary between immigrants' human capital skills and their earnings. Nearly 60 percent of immigrants' earnings gains in the US can be attributed to inter-occupational earnings differences, with just over 40 percent to intra-occupational differences, in contrast to 55 or 45 percent for native-born men in the US.

\footnotetext{
${ }^{1}$ Positive selectivity can arise from the supply side (incentives for migration) or the demand side (criteria for allocating visas) of the market for immigrants.

${ }^{2}$ For an application for the US unrelated to immigration see Sicherman and Golar (1990).
} 
The comparison of the Australian analyses in this paper with the Chiswick and Miller (2007) findings is particularly relevant given the difference in the primary focus in rationing immigrant visas, the applicant's skills in Australia and family reunification in the United States.

The structure of this paper is as follows. Section II reviews the data from the 2001 Australian Census of Population and Housing that is used in the statistical analyses, with a special emphasis on the information on occupation. It also outlines the specification of the estimating equation. Empirical results from the analysis of earnings are presented in Section III. Section IV provides information on the determinants of occupational attainment that assists in the explanation of the findings reported in Section III. A summary and conclusion are provided in Section V.

\section{Data and Earnings Equation}

The data are from the 2001 Australian Census of Population and Housing one percent sample of households (Australian Bureau of Statistics, 2003). They include information on age, birthplace, educational attainment, marital status, current employment status, earnings and occupation, among other variables. The Expanded Confidentialized Unit Record Files (CURF) available only through the Remote Access Data Laboratory (RADL) is used in this study. ${ }^{3}$

The information on occupation is coded according to the Australian Standard Classification of Occupations (ASCO), second edition (Australian Bureau of Statistics, 1997). In the one percent sample only 44 occupational categories are distinguished (See Appendix A). These are used in two forms in the analyses. First, the 44 occupational categories are aggregated into the nine ASCO Major Groups. Second, all of the 44 separate occupational categories are used as the basis of the empirical investigation. ${ }^{4}$

\footnotetext{
${ }^{3}$ The RADL is an on-line database query system, under which microdata are held on a server at the Australian Bureau of Statistics (ABS) in Canberra. Registered users are able to submit programs (e.g., SAS, SPSS) to analyze the data.

${ }^{4}$ Due to the 15 -fold difference in population size, this level of detail is less than that utilised in the research for the US by Chiswick and Miller (2007), where the aggregatelevel analysis was based on 23 occupational categories, and the more disaggregated analysis on over 500 occupations.
} 
The analyses are restricted to males aged 20-64 who were employed on a fulltime basis (i.e., they worked 35 or more hours per week) in the week before Census night and who reported positive weekly earnings. Appendix B contains definitions of all variables and a table of means and standard deviations.

The earnings function initially estimated takes the following form:

$$
\ln Y_{i}=Z_{i} \beta+\varepsilon_{i}
$$

where the dependent variable is the natural logarithm of weekly earnings, $Z_{i}$ is a vector of the individual and job-related characteristics that affect the earnings of individual $i, \varepsilon_{i}$ is the error term, and $\beta$ is a vector of parameters to be estimated. The variables considered in $Z$ consist of years of schooling, labour market experience and its square, dichotomous variables for government employment, marital status, and birthplace (Australia or foreign born), and variables for duration of residence for immigrants and English language proficiency. Controlling for duration in Australia, the labour market experience variables measure the effect on earnings of pre-immigration labour market experience.

The estimates obtained from equation (1) provide a benchmark set of results for the links between productivity related characteristics and earnings. Two extensions of equation (1) are considered. The first of these involves augmentation with dichotomous variables for the Major Group occupations. Eight dichotomous variables are considered, with Managers and Administrators as the benchmark group. The second extension involves including dichotomous variables for each of the 44 occupations included in the Census classification.

Each of these extensions controls for the occupational earnings structure, albeit at different levels of detail. The coefficients on the variables for occupation provide information on the effect on earnings of employment in the particular occupation. This is a direct effect of occupation on earnings. With occupation held constant, the coefficients of the other explanatory variables reflect their effect on earnings within occupations. Hence, comparison of the estimates in the equation with the occupation variables with estimates from the benchmark equation (1) provide information on the effect of these variables on earnings through intra- and inter-occupational change. 


\section{Analysis for Earnings}

\section{(i) Earnings Functions}

The results from these analyses are presented in Table 1 and summarised in Table 2. These tables have separate panels for the Australian born, immigrants from Englishspeaking developed countries, and immigrants from non-English-speaking countries.

The payoff to years of schooling declines by between 24 and 47 percent when the occupational structure is taken into account at the major group level (9 occupational categories). The largest decline is for immigrants from non-English-speaking countries, and the smallest is for the Australian born. For immigrants from non-English-speaking countries, these results indicate that almost one-half of the increase in earnings associated with each extra year of schooling comes about through this extra schooling facilitating access to higher paying occupations.

There are further reductions in the payoff to schooling when the finer degree of detail on occupation is included in the estimating equation. Among the Australian born, the payoff to schooling falls by 41 percent, from 8.8 percent to 5.2 percent. The change in the payoff to schooling for the foreign born from English-speaking countries is similar: it falls from 8.1 percent to 4.6 percent, a 43 percent reduction. In other words, slightly more than 40 percent of the increments in earnings associated with extra years of schooling for immigrants from English-speaking countries derives from inter-occupational earnings differences, and slightly less than 60 percent derives from increases in earnings within occupations.

Among immigrants from non-English-speaking countries, however, the payoff to a year of schooling falls from 5.8 to 2.0 percent when account is taken of employment in the 44 occupations. This is a 66 percent reduction in the payoff to schooling. In other words, two-thirds of the payoff to schooling for immigrants from non-English-speaking countries is associated with access to higher paying occupations. Schooling is indicated here as being of far greater importance for earnings via occupational change for immigrants from non-English-speaking countries than it is for immigrants educated in Australia or other English-speaking countries. 
Table 1

Estimates of Earnings Functions by Birthplace, Males Aged 20-64 Years, 2001 ${ }^{(\mathrm{a})}$

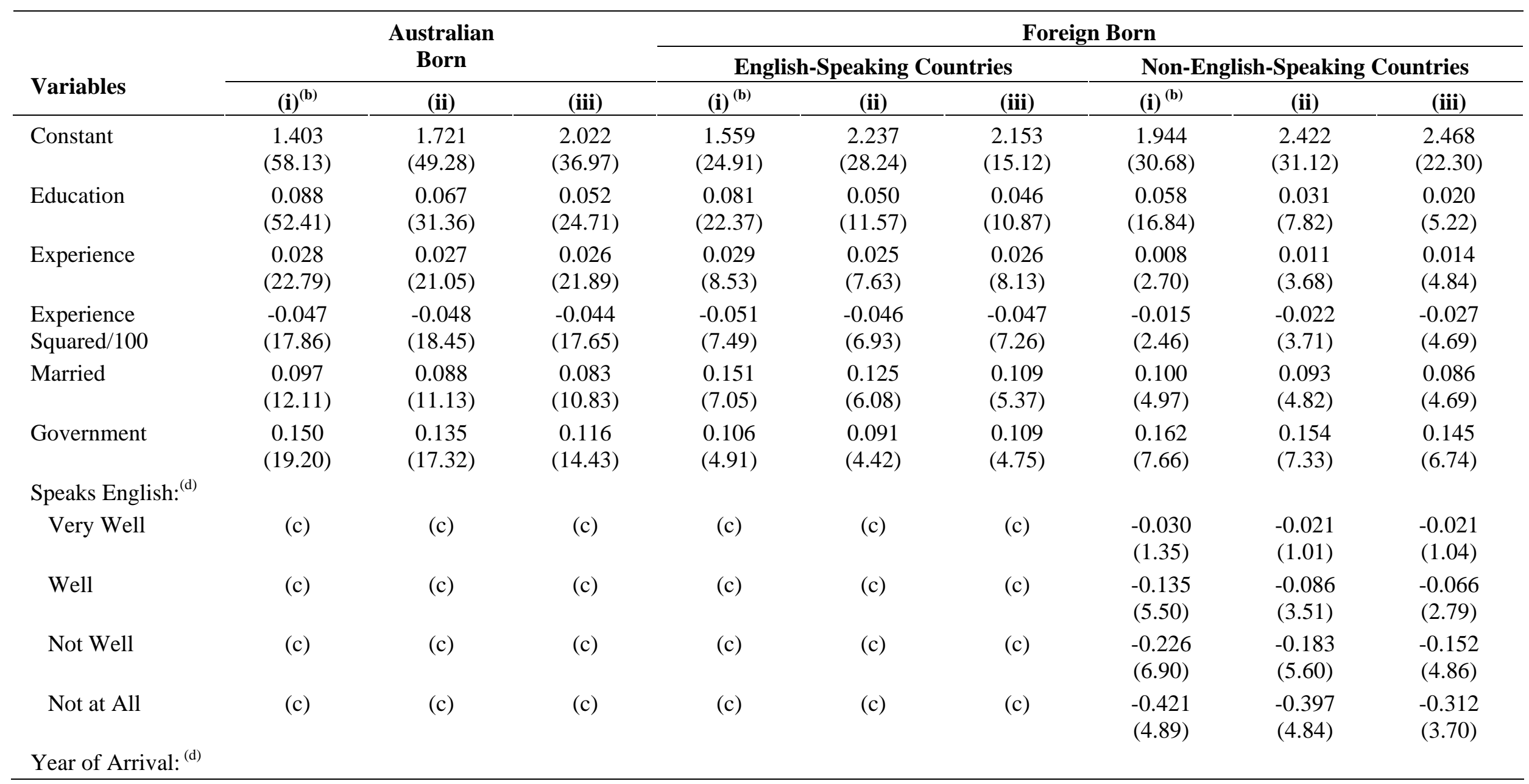




\begin{tabular}{|c|c|c|c|c|c|c|c|c|c|}
\hline 1991-1995 & (c) & (c) & (c) & $\begin{array}{l}-0.040 \\
(0.92)\end{array}$ & $\begin{array}{c}-0.033 \\
(0.81)\end{array}$ & $\begin{array}{r}-0.030 \\
(0.76)\end{array}$ & $\begin{array}{l}0.011 \\
(0.32)\end{array}$ & $\begin{array}{c}0.025 \\
(0.75)\end{array}$ & $\begin{array}{l}0.012 \\
(0.39)\end{array}$ \\
\hline 1986-1990 & (c) & (c) & (c) & $\begin{array}{l}-0.055 \\
(1.58)\end{array}$ & $\begin{array}{r}-0.030 \\
(0.92)\end{array}$ & $\begin{array}{c}-0.026 \\
(0.85)\end{array}$ & $\begin{array}{c}0.031 \\
(0.99)\end{array}$ & $\begin{array}{c}0.039 \\
(1.31)\end{array}$ & $\begin{array}{l}0.030 \\
(1.04)\end{array}$ \\
\hline Occupation ${ }^{(\mathrm{e})}$ & NI & INC & INC & NI & INC & INC & NI & INC & INC \\
\hline $\bar{R}^{2}$ & 0.190 & 0.210 & 0.291 & 0.194 & 0.256 & 0.306 & 0.168 & 0.223 & 0.300 \\
\hline
\end{tabular}

Notes: (a) Heteroscedasticity-consistent ' $t$ ' statistics in parentheses; (b) specification (i) is the benchmark model that does not contain information on occupation, specification (ii) contains dichotomous variables for the Major Group occupations, while specification (iii) contains dichotomous variables for the more detailed (44) Census occupational categories; (c) = Variables not entered; (d) = The omitted category for the Speaks English variable is "Speaks only English" and that for the Year of Arrival variable is “After 1995”; (e) NI = Occupation Not Included, INC = Occupation Included.

Source: 2001 Australian Census of Population and Housing. 
Table 2

Payoffs to Selected Characteristics from Analysis of Earnings, by Birthplace, Males Aged 20-64, 2001

\begin{tabular}{|c|c|c|c|c|c|}
\hline \multirow[b]{2}{*}{ Variable } & \multicolumn{3}{|c|}{ Payoffs from Earnings Function } & \multicolumn{2}{|c|}{ \% Change } \\
\hline & Standard & $\begin{array}{c}\text { Controlling } \\
\text { for } 9 \\
\text { Occupations } \\
\end{array}$ & $\begin{array}{c}\begin{array}{c}\text { Controlling } \\
\text { for } 44 \\
\text { Occupations }\end{array} \\
\end{array}$ & $\begin{array}{c}\text { With } 9 \\
\text { Occupations } \\
\end{array}$ & $\begin{array}{c}\text { With } 44 \\
\text { Occupations }\end{array}$ \\
\hline \multicolumn{6}{|c|}{ A. Australian Born } \\
\hline \multicolumn{5}{|c|}{$\overline{\text { Educational }}$} & -40.9 \\
\hline $\begin{array}{l}\text { Experience } \\
\text { - } 10 \text { years } \\
\text { - } 20 \text { years }\end{array}$ & $\begin{array}{l}1.86 \\
0.92\end{array}$ & $\begin{array}{l}1.74 \\
0.78\end{array}$ & $\begin{array}{l}1.72 \\
0.84\end{array}$ & $\begin{array}{l}-6.5 \\
-15.2\end{array}$ & $\begin{array}{l}-7.5 \\
-8.7\end{array}$ \\
\hline \multicolumn{6}{|c|}{ B. Overseas Born, English-speaking Developed Countries } \\
\hline $\begin{array}{l}\text { Educational } \\
\text { Attainment }\end{array}$ & 8.1 & 5.0 & 4.6 & -38.3 & -43.2 \\
\hline \multicolumn{6}{|l|}{$\begin{array}{l}\text { Pre- } \\
\text { Immigration } \\
\text { Experience }\end{array}$} \\
\hline $\begin{array}{l}-10 \text { years } \\
-20 \text { years }\end{array}$ & $\begin{array}{l}1.88 \\
0.86\end{array}$ & $\begin{array}{l}1.58 \\
0.66\end{array}$ & $\begin{array}{l}1.66 \\
0.72\end{array}$ & $\begin{array}{l}-16.0 \\
-23.3\end{array}$ & $\begin{array}{l}-11.7 \\
-16.3\end{array}$ \\
\hline $\begin{array}{l}\text { Migrated } \\
\text { Before } 1986\end{array}$ & -8.5 & -7.7 & \multicolumn{3}{|c|}{ Migrated } \\
\hline \multicolumn{6}{|c|}{ C. Overseas Born, non-English-speaking Countries } \\
\hline $\begin{array}{l}\text { Educational } \\
\text { Attainment }\end{array}$ & 5.8 & 3.1 & 2.0 & -46.6 & -65.5 \\
\hline \multicolumn{6}{|l|}{$\begin{array}{l}\text { Pre- } \\
\text { Immigration } \\
\text { Experience }\end{array}$} \\
\hline - 10 years & 0.5 & 0.66 & 0.86 & 32.0 & 72.0 \\
\hline - 20 years & 0.2 & 0.22 & 0.32 & 10.0 & 60.0 \\
\hline $\begin{array}{l}\text { Migrated } \\
\text { Before } 1986\end{array}$ & 10.7 & 10.0 & 8.3 & -6.5 & -22.4 \\
\hline $\begin{array}{l}\text { Speaks } \\
\text { English }\end{array}$ & & & & & \\
\hline Well & -13.5 & -8.6 & -6.6 & -36.3 & -51.1 \\
\hline Not Well & -22.6 & -18.3 & -15.2 & -19.0 & -32.7 \\
\hline Not at All & -42.1 & -39.7 & -31.2 & -5.7 & -25.9 \\
\hline
\end{tabular}

Source: Authors' calculations based on Table 1. 
There is minimal change to the payoff to labour market experience for those born in Australia, with the reduction ranging from 7 to 15 percent. This implies that labour market experience has only a modest impact on occupational status for those born in Australia.

The control for occupation has a slightly greater impact on the payoff to preimmigration experience for immigrants from English-speaking countries. This ranges from 12 to 23 percent. Among immigrants from non-English-speaking countries, the pattern of effects is quite different, with the payoff to pre-immigration labour market experience rising once account is taken of occupation. Evaluated at 10 years, the payoff to pre-immigration labour market experience rises from 0.5 percent per year in the benchmark model, to 0.66 percent (a 32 percent increase) following control for Major Group occupation. It rises further to 0.86 percent (a 72 percent increase over the benchmark model) when dichotomous variables for the 44 Census occupations are included in the model.

The immigrant duration variables (i.e., post-migration experience) have opposite patterns for the two groups of immigrants. Immigrants from non-English-speaking countries who arrived before 1986 are shown to have significantly greater earnings than the most recent arrivals (1996-2001). This earnings advantage falls by between 7 and 22 percent once occupation is held constant. Immigrants from English-speaking countries, however, who arrived in the past five years are shown to have relatively high earnings, though their earnings position only differs significantly from the group who arrived before $1986^{5}$.

Finally, it is seen that there are pronounced changes to the earnings effects associated with English proficiency following the incorporation of information on occupation into the earnings equation. The changes range from 6 to 36 percent when the information on Major Group occupation is used, and from 26 to 51 percent when the information on all 44 Census occupational categories is used.

\footnotetext{
${ }^{5}$ For an analysis of the apparent decline in earnings with duration of residence among immigrants from the English-speaking developed countries, see Chiswick and Miller (2008).
} 
These changes in the estimated effects as the earnings equation is augmented with information on occupation follow the pattern found for the US labour market by Chiswick and Miller (2007). Comparison of Table 2 for Australia and Table 3 for the US reveals that the changes in the effects of educational attainment on earnings following standardisation for occupation are broadly the same in Australia and the United States. While precise estimates of the differences in the relative magnitudes of the changes in Australia and the United States due to holding occupation constant are hard to assess, given the different definitions of the variables and the level of detail on occupation, it appears that inter-occupational earnings differences are greater in the payoff to education in Australia than in the US. This may follow from the more centralised system of wage determination, and perhaps greater union power, in Australia than in the US, and as a result the more egalitarian distribution of earnings within each occupation (see Miller, Mulvey and Martin, 1995).

The impact of taking account of occupation in the earnings function on the payoff to experience is also broadly the same for immigrants from non-English-speaking countries in Australia (Table 2) and for immigrants in the United States (Table 3).

Similar changes are associated with limited English skills in the two labour markets. There is a reduction in the earnings disadvantage associated with limited English skills when occupation is held constant, or equivalently, part of the earnings advantage associated with better English language skills comes about through these skills facilitating the workers' access to higher paying occupations. The changes in the partial effects of English-language proficiency are greater in the Australian labour market than is the case in the US labour market for those who report they speak English very well, but smaller for those with a lower level of proficiency.

Using the standard formula for analysing omitted variables bias, the changes in the estimated coefficients summarised in Table 2 are due to two sets of factors. First, there is the independent effect that occupation has on earnings in the augmented equation. Second, there are the correlations between the other explanatory variables (such as educational attainment) and occupation. The differences in the effects that controlling for occupation has on the partial effects of educational attainment, duration, pre-immigration labour market experience and the English proficiency variables for the Australian born 
and immigrants must therefore be due to both of these factors. If either one is zero, the effect of the explanatory variable is the same in the benchmark and the augmented equation.

Table 3

Payoffs to Selected Characteristics from Analysis of Earnings, by Birthplace, Males Aged 25-64, 2000 US Census

\begin{tabular}{|c|c|c|c|c|c|}
\hline \multirow[b]{2}{*}{ Variable } & \multicolumn{3}{|c|}{ Payoffs from Earnings Function } & \multicolumn{2}{|c|}{ \% Change } \\
\hline & Standard & $\begin{array}{c}\text { Controlling } \\
\text { for } 23 \\
\text { Occupations } \\
\end{array}$ & $\begin{array}{c}\text { Controlling } \\
\text { for } 509 \\
\text { Occupations } \\
\end{array}$ & $\begin{array}{c}\text { With } 23 \\
\text { Occupations } \\
\end{array}$ & $\begin{array}{c}\text { With } 509 \\
\text { Occupations }\end{array}$ \\
\hline A. US Born & & & & & \\
\hline $\begin{array}{l}\text { Educational } \\
\text { Attainment }\end{array}$ & 10.6 & 8.2 & 5.8 & -23 & -45 \\
\hline $\begin{array}{l}\text { Experience } \\
\text { - } 10 \text { years } \\
\text { - } 20 \text { years }\end{array}$ & $\begin{array}{l}2.16 \\
1.02\end{array}$ & $\begin{array}{l}2.16 \\
1.02\end{array}$ & $\begin{array}{l}2.10 \\
1.00\end{array}$ & $\begin{array}{l}0 \\
0\end{array}$ & $\begin{array}{l}-3 \\
-2\end{array}$ \\
\hline B. Foreign Bo & & & & & \\
\hline $\begin{array}{l}\text { Educational } \\
\text { Attainment }\end{array}$ & 5.3 & 3.2 & 2.3 & -40 & -57 \\
\hline $\begin{array}{l}\text { Pre- } \\
\text { Immigration } \\
\text { Experience }\end{array}$ & & & & & \\
\hline $\begin{array}{l}\text { - } 10 \text { years } \\
\text { - } 20 \text { years }\end{array}$ & $\begin{array}{l}0.88 \\
0.56\end{array}$ & $\begin{array}{l}1.24 \\
0.68\end{array}$ & $\begin{array}{l}1.30 \\
0.70\end{array}$ & $\begin{array}{l}+41 \\
+21\end{array}$ & $\begin{array}{l}+48 \\
+25\end{array}$ \\
\hline $\begin{array}{l}\text { Years Since } \\
\text { Migration }\end{array}$ & & & & & \\
\hline $\begin{array}{l}-10 \text { years } \\
-20 \text { years }\end{array}$ & $\begin{array}{l}0.88 \\
0.66\end{array}$ & $\begin{array}{l}0.96 \\
0.72\end{array}$ & $\begin{array}{l}0.92 \\
0.64\end{array}$ & $\begin{array}{l}+9 \\
+9\end{array}$ & $\begin{array}{l}+5 \\
-3\end{array}$ \\
\hline $\begin{array}{l}\text { Speaks } \\
\text { English }\end{array}$ & & & & & \\
\hline Very Well & -8.0 & -7.1 & -5.7 & -11.3 & -28.8 \\
\hline Well & -26.1 & -17.7 & -13.4 & -32.2 & -48.7 \\
\hline Not Well & -37.3 & -26.9 & -21.7 & -27.9 & -41.8 \\
\hline Not at All & -37.8 & -30.0 & -25.2 & -20.6 & -33.3 \\
\hline
\end{tabular}

Note: Only 11 percent of the foreign born were from English-speaking developed countries.

Source: Chiswick and Miller (2007).

(ii) Occupation Fixed Effects

Differences in the impact of occupation on earnings across the three birthplace groups can be assessed informally by plotting the fixed effects from the respective 
earnings equations. Figures 1 and 2, respectively, present the plot of the estimated occupational "fixed effects" coefficients from the model for the Australian born against the "fixed effects" coefficients for immigrants from English-speaking countries and nonEnglish-speaking countries. The straight line AA in these figures is the simple regression of the coefficients on occupation for the Australian born on the coefficients for immigrants from English-speaking countries and non-English-speaking countries, respectively. ${ }^{6}$

Figure 1

Occupational Fixed Effects in Natural Logarithmic Form for the Australian Born and for Immigrants from English-Speaking Countries, 2001

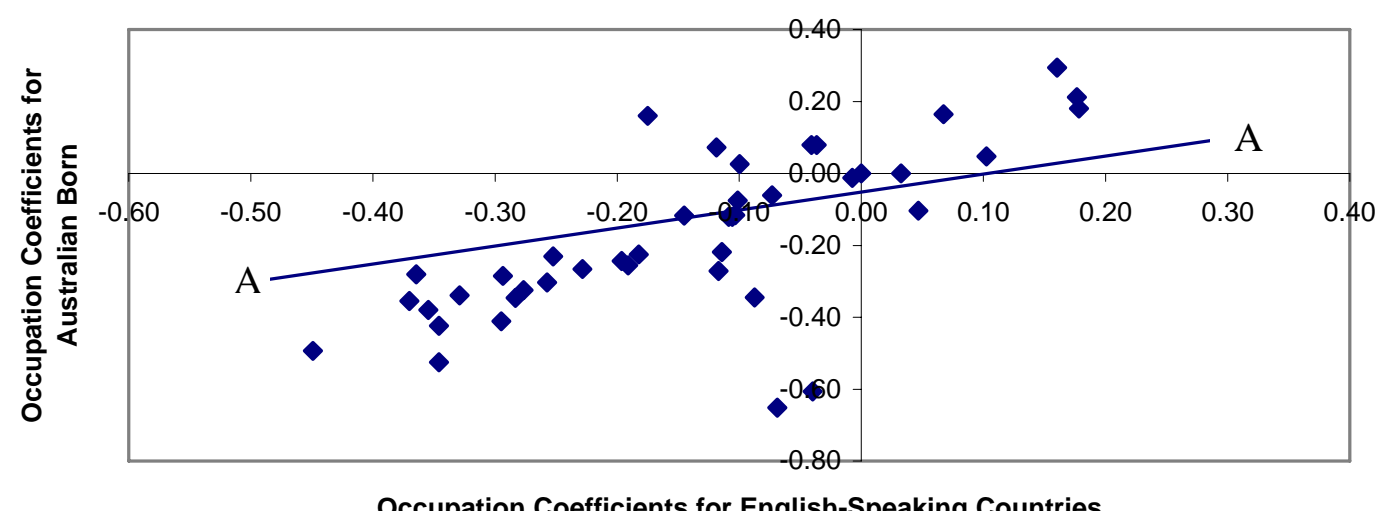

Note: The benchmark occupation in the analysis is Managers and Administrators n.f.d. It has a coefficient of zero for both birthplace groups in the Figure.

Source: Table 1, column (iii) specification.

\footnotetext{
${ }^{6}$ To ascertain whether these relationships are due to immigrant occupational crowding, the difference in the occupational fixed effects between the Australian born and immigrants from English-speaking countries was related to the proportional representation of immigrants from English-speaking countries in each occupation and to differences in the proportional representation of the Australian born and immigrants from English-speaking countries. The findings did not support this possibility. This is also the case for the occupational fixed effects for immigrants from non-English-speaking countries (Figure 2).
} 
Figure 2

Occupational Fixed Effects in Natural Logarithmic Form for the Australian Born and for Immigrants from Non-English-Speaking Countries, 2001

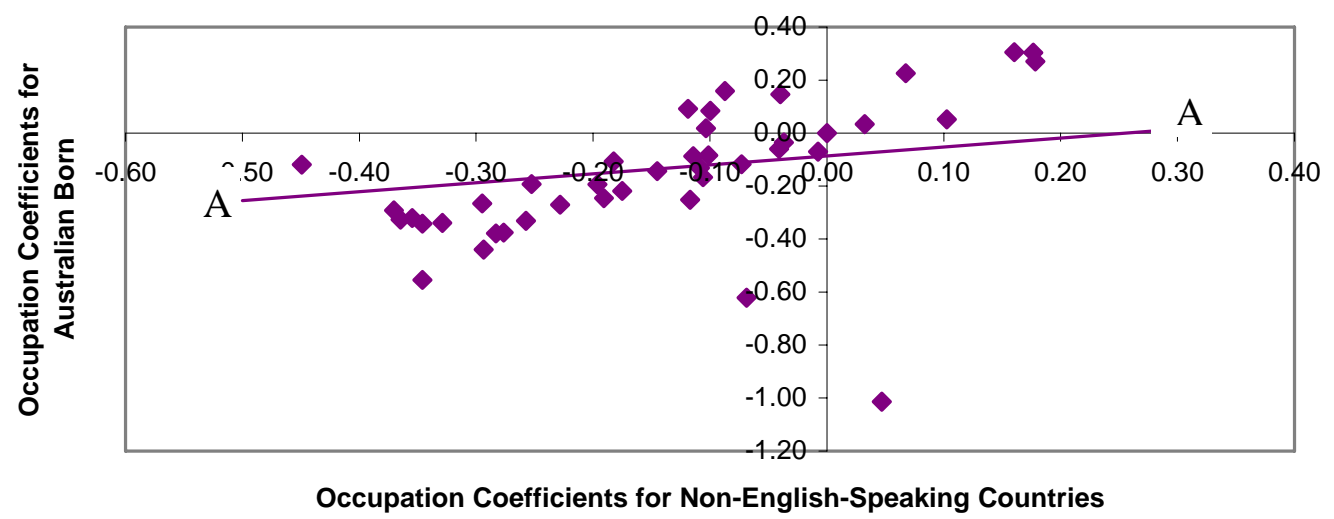

Note: The benchmark occupation in the analysis is Managers and Administrators n.f.d. It has a coefficient of zero for both birthplace groups in the Figure.

Source: Table 1, column (iii) specification.

It is clear from Figures 1 and 2 that relatively high-paying occupations for one birthplace group are generally also relatively high-paying occupations for the other birthplace groups. The correlation coefficient between the occupational fixed effects in Figure 1 is 0.716 , while that for Figure 2 is $0.549 .^{7}$ If the data points are weighted by the employment shares of the immigrant groups the correlation coefficients are 0.889 and 0.917, respectively. If the occupational employment shares of the Australian born are used then the correlation coefficients are somewhat lower, 0.796 and 0.840 , respectively.

These comparisons of the occupational fixed effects suggest that they are so close that they are not likely to be the main contributor to the different pattern of results across

\footnotetext{
${ }^{7}$ There are, however, three occupations (Other Intermediate Production and Transport Workers, Farmers and Farm Managers, and Intermediate Production and Transport Workers n.f.d.) for immigrants from English-speaking countries that do no follow closely the pattern for the Australian born. Similarly, there are three occupations (Labourer and Related Workers n.f.d., Farmer and Farm Managers, and Secretaries and Personal Assistant) for immigrants from non-English-speaking countries where the earnings fixed effects diverge from the respective fixed effects for the Australian born. These occupations, however, are of relatively minor importance, accounting for less than five percent of the respective immigrant group's employment. When the atypical occupations are removed from the analysis, these correlation coefficients rise to 0.904 and 0.898 , respectively.
} 
birthplace groups in Table 2. Given these findings, the explanation for the differences in the estimates of the earnings equation between the Australian born and the foreign born when occupation is held constant needs to focus on the partial effects of the explanatory variables on occupational choice.

\section{Occupational Attainment}

This section presents estimates of a model of occupational attainment that assists in accounting for the pattern of effects reported in Table 2. A model in the tradition of the status attainment models of Nickell (1982) and Evans (1987) is employed. Hence, the analysis proposed is the estimation (using OLS) of a status attainment model:

$$
\mathrm{Occ}_{i}=\alpha X_{i}+v_{i}
$$

where $O c c_{i}$ is the mean occupational earnings of the Census occupational category (i.e., mean earnings in each of the 44 Census occupations) in which individual $i$ works, $X_{i}$ is a set of the individual's attributes that influences this occupational outcome, and $v_{i}$ is a random error term. As a check on the robustness of the empirical findings, ordered probit models are also estimated using mean occupational earnings as the ranking instrument. ${ }^{8}$

Table 4 contains two sets of OLS estimates of the status attainment model for each birthplace group. Specification (i) is based on mean occupational earnings for the nine major group occupations, while specification (ii) is for mean occupational earnings for the 44 Census occupational categories.

\footnotetext{
${ }^{8}$ Status attainment models involve first characterizing occupations by a measure of "status," and using this measure as the dependent variable in a linear regression. Nickell (1982) uses the mean earnings for each occupation. Evans (1987) uses a status attainment score. While status attainment scores are usually viewed as being more encompassing than mean occupational earnings (see Duncan, 1961), although they are based in part on earnings, which is a focus of this paper.
} 
Table 4

Estimates of Model of Occupational Status, with the Mean Occupational Earnings as the Dependent Variable, by Birthplace, Males Aged 20-64, 2001 ${ }^{\text {(a) }}$

\begin{tabular}{|c|c|c|c|c|c|c|}
\hline \multirow[b]{3}{*}{ Variables } & & & \multicolumn{4}{|c|}{ Foreign Born } \\
\hline & \multicolumn{2}{|c|}{ Australian Born } & \multicolumn{2}{|c|}{$\begin{array}{c}\text { English-Speaking } \\
\text { Countries }\end{array}$} & \multicolumn{2}{|c|}{$\begin{array}{c}\text { Non-English-Speaking } \\
\text { Countries }\end{array}$} \\
\hline & (i) ${ }^{(\mathbf{b})}$ & (ii) & (i) (b) $^{(b)}$ & (ii) & (i) ${ }^{(b)}$ & (ii) \\
\hline Constant & $\begin{array}{c}2.245 \\
(307.27)\end{array}$ & $\begin{array}{c}2.054 \\
(210.94)\end{array}$ & $\begin{array}{c}2.269 \\
(90.91)\end{array}$ & $\begin{array}{c}2.202 \\
(71.72)\end{array}$ & $\begin{array}{c}2.412 \\
(100.39)\end{array}$ & $\begin{array}{c}2.299 \\
(75.76)\end{array}$ \\
\hline Education & $\begin{array}{c}0.048 \\
(97.25)\end{array}$ & $\begin{array}{c}0.062 \\
(94.10)\end{array}$ & $\begin{array}{c}0.051 \\
(38.67)\end{array}$ & $\begin{array}{c}0.055 \\
(33.85)\end{array}$ & $\begin{array}{c}0.041 \\
(35.14)\end{array}$ & $\begin{array}{c}0.050 \\
(34.49)\end{array}$ \\
\hline Experience & $\begin{array}{l}0.001 \\
(3.59)\end{array}$ & $\begin{array}{l}0.004 \\
(7.58)\end{array}$ & $\begin{array}{l}0.005 \\
(3.13)\end{array}$ & $\begin{array}{l}0.005 \\
(2.86)\end{array}$ & $\begin{array}{l}-0.005 \\
(3.64)\end{array}$ & $\begin{array}{l}-0.006 \\
(3.81)\end{array}$ \\
\hline $\begin{array}{l}\text { Experience } \\
\text { Squared/100 }\end{array}$ & $\begin{array}{l}0.003 \\
(3.29)\end{array}$ & $\begin{array}{l}-0.004 \\
(3.39)\end{array}$ & $\begin{array}{l}-0.006 \\
(1.96)\end{array}$ & $\begin{array}{l}-0.007 \\
(2.13)\end{array}$ & $\begin{array}{l}0.011 \\
(4.74)\end{array}$ & $\begin{array}{l}0.013 \\
(4.58)\end{array}$ \\
\hline Married & $\begin{array}{l}0.017 \\
(6.40)\end{array}$ & $\begin{array}{l}0.022 \\
(5.82)\end{array}$ & $\begin{array}{l}0.036 \\
(3.97)\end{array}$ & $\begin{array}{l}0.054 \\
(5.03)\end{array}$ & $\begin{array}{l}0.010 \\
(1.21)\end{array}$ & $\begin{array}{l}0.017 \\
(1.62)\end{array}$ \\
\hline \multicolumn{7}{|c|}{ Speaks English: ${ }^{(d)}$} \\
\hline Very Well & (c) & (c) & (c) & (c) & $\begin{array}{l}-0.013 \\
(1.67)\end{array}$ & $\begin{array}{l}-0.015 \\
(1.44)\end{array}$ \\
\hline Well & (c) & (c) & (c) & (c) & $\begin{array}{l}-0.084 \\
(9.33)\end{array}$ & $\begin{array}{l}-0.105 \\
(8.98)\end{array}$ \\
\hline Not Well & (c) & (c) & (c) & (c) & $\begin{array}{l}-0.085 \\
(7.55)\end{array}$ & $\begin{array}{l}-0.123 \\
(8.31)\end{array}$ \\
\hline Not at All & (c) & (c) & (c) & (c) & $\begin{array}{l}-0.032 \\
(1.01)\end{array}$ & $\begin{array}{l}-0.146 \\
(3.71)\end{array}$ \\
\hline \multicolumn{7}{|c|}{ Year of Arrival:(d) } \\
\hline 1991-1995 & (c) & (c) & $\begin{array}{l}-0.011 \\
(0.63)\end{array}$ & $\begin{array}{l}-0.006 \\
(0.32)\end{array}$ & $\begin{array}{l}-0.016 \\
(1.09)\end{array}$ & $\begin{array}{l}0.000 \\
(0.01)\end{array}$ \\
\hline $1986-1990$ & (c) & (c) & $\begin{array}{l}-0.033 \\
(2.41)\end{array}$ & $\begin{array}{l}-0.029 \\
(1.71)\end{array}$ & $\begin{array}{l}-0.005 \\
(0.36)\end{array}$ & $\begin{array}{l}0.003 \\
(0.19)\end{array}$ \\
\hline Before 1986 & (c) & (c) & $\begin{array}{l}-0.009 \\
(0.77)\end{array}$ & $\begin{array}{l}-0.011 \\
(0.83)\end{array}$ & $\begin{array}{l}0.016 \\
(1.22)\end{array}$ & $\begin{array}{l}0.035 \\
(2.25)\end{array}$ \\
\hline $\bar{R}^{2}$ & 0.321 & 0.278 & 0.281 & 0.253 & 0.330 & 0.321 \\
\hline Sample Size & 20,709 & 20,709 & 3,127 & 3,127 & 3,752 & 3,752 \\
\hline $\begin{array}{ll}\text { Notes: } & \text { (a) } \mathrm{H} \\
& \text { mean }\end{array}$ & $\begin{array}{l}\text { scedastic } \\
\text { upational } \\
\text { on has th } \\
\text { variable; } \\
\text { "Speaks }\end{array}$ & $\begin{array}{l}\text { Sistent 't } \\
\text { igs at th } \\
\text { 1 occupa } \\
\text { Variables } \\
\text { nglish" ? }\end{array}$ & $\begin{array}{l}\text { Cs in pare } \\
\text { Group l } \\
\text { rnings at } \\
\text { ered; (d) } \\
\text { or the Ye }\end{array}$ & $\begin{array}{l}\text { Ses; (b) } \\
\text { as the } \\
\text { Census } \\
\text { omittec } \\
\text { Arrival }\end{array}$ & $\begin{array}{l}\mathrm{mn} \text { (i) spe } \\
\text { dent vari } \\
\text { ational cla } \\
\text { gory for th } \\
\text { ble is " } \mathrm{Aft}\end{array}$ & $\begin{array}{l}\text { tion has the } \\
\text { column (ii) } \\
\text { ation as the } \\
\text { aks English } \\
5 \text { ". }\end{array}$ \\
\hline
\end{tabular}


The estimates in Table 4 for the Australian born show that the main determinant of occupational status, as measured by the t-ratio and magnitude of the partial effect, is educational attainment. Each year of schooling is associated with entry into occupations having 5 (specification (i)) to 6 (specification (ii)) percent higher earnings. In comparison, for men born in Australia, the effects on mean occupational earnings of labour market experience are very small, and sensitive to the level of aggregation of the occupational categories. Under either classification, the difference in mean occupational earnings between the least and most experienced workers is less than the effect of two years of schooling. Thus, among the native born, schooling is a far more important determinant of occupational attainment than is labour market experience. A similar pattern is found among the native born in the United States (Chiswick and Miller, 2007).

The results for immigrants from English-speaking countries are similar to the findings among the Australian born. While additional education apparently readily opens up access to higher-paying occupations, additional years of pre-immigration and postimmigration labour market experience are not associated with similar access.

Among the foreign born from non-English-speaking countries, years of education are also associated with higher mean occupational earnings, with the partial effect of 0.041 to 0.050 being around one percentage point less than that estimated for the other birthplace groups. This finding is consistent with the smaller partial effects of education on individual earnings among immigrants from non-English-speaking countries in Table 1. However, immigrants from non-English-speaking countries with moderate amounts of pre-immigration labour market experience have relatively low mean occupational earnings compared to those with even less pre-immigration experience. This is the same finding as in Chiswick and Miller (2007), on the basis of study of the US labour market. The finding is consistent with the increase in the payoff to labour market experience once occupation is held constant in the study of individual earnings (Tables 1 and 2). The effect of duration in Australia has a positive effect on mean occupational earnings, but this effect is also quite modest.

Finally, it is noted that proficiency in English is associated with substantial occupational advancement, though the estimated coefficients in Table 4 are only around 
one-half the magnitude of the effects found in the study of individual earnings (without the variables for occupation) in Table 1.

Findings similar to these are obtained when an ordered probit model is applied to the occupational data (ranked by mean earnings). ${ }^{9}$ In particular, the main determinant of membership in a higher-ranked occupation is educational attainment. The effects of labour market experience on occupational outcomes for immigrants from non-Englishspeaking countries is opposite those estimated for the Australian born and immigrants from English-speaking countries. English proficiency is a major determinant of the likelihood of being employed in a high-earnings occupation among immigrants from nonEnglish-speaking countries.

\section{$V$ Conclusion}

The analyses for Australia using the 2001 Census data on adult men in full-time employment reported in this paper show that when occupation is held constant in the earnings equation, there is a reduction of 41 percent in the payoff to schooling for the Australian born, a similar reduction, of 43 percent, in the payoff to schooling for immigrants from English-speaking developed countries, and an even greater reduction, by 66 percent, in the payoff to schooling for immigrants from other countries. The latter have a much lower transferability of their skills to Australia.

At the same time, holding occupation constant is associated with a quite modest reduction, of less than 10 percent, in the payoff to labour market experience for the Australian born. It is also associated with only a minor reduction, of around 16 percent, in the payoff to pre-immigration experience for immigrants from English-speaking countries. However, controlling for occupation increases the payoff to pre-immigration labour market experience by 60 to 70 percent for immigrants from non-English-speaking countries. These remarkable differences are due to a negative association between occupational status in Australia and pre-immigration labour market experience for many immigrants from non-English-speaking countries. This may arise if there is negative

\footnotetext{
${ }^{9}$ These results are not presented here, as the information content is broadly the same as Table 4 . The results are available from the authors upon request.
} 
selectivity among those from low transferability countries who immigrate to Australia at an older age, which is after many years of work experience in their country of origin.

The comparison of the findings for the Australian labour market with the study by Chiswick and Miller (2007) for the US labour market revealed that inter-occupational earnings mobility is of greater importance in gaining a payoff to education in Australia than in the US. This is likely to be linked to the more egalitarian distribution of earnings within occupations that is associated with the more centralised system of wage determination, and perhaps greater union power, in Australia than in the US.

These findings suggest that attention needs to be focussed on occupational outcomes at the time of labour market entry in the destination country. The different immigrant selection regimes of the US (emphasis on family reunion) and Australia (emphasis on skills) do not appear to matter in this regard. More fundamental labour market processes seem to be at work. The study of occupational attainment for subgroups of the population who may face different transitions (e.g., have access to well established networks or settle in areas with tight labour markets) may assist in understanding these processes. 


\section{REFERENCES}

Australian Bureau of Statistics, (1997). Australian Standard Classification of Occupations, Second Edition, Catalogue No. 1220.0, Australian Government Publishing Service, Canberra.

Australian Bureau of Statistics, (2003). Technical Paper: Census of Population and Housing Household Sample File Australia 2001, Catalogue No. 2037.0, Australian Bureau of Statistics, Canberra.

Chiswick, B., (1978). 'The Effects of Americanization on the Earnings of Foreign Born Men', Journal of Political Economy, 86, 897-921.

Chiswick, B.R. and Miller, P.W., (2007). 'Earnings and Occupational Attainment: Immigrants and the Native Born', IZA-Institute for the Study for Labor, Bonn, Discussion Paper No. 2676, March.

Chiswick, B.R. and Miller, P.W. (2008). 'The "Negative” Assimilation of Immigrants: A Special Case’, photocopy, Business School, The University of Western Australia, Crawley, WA, Australia.

Duncan, O.D., (1961). 'Properties and Characteristics of the Socioeconomic Index', in Albert J. Reiss Jr (ed.), Occupational and Social Status, New York: Free Press, 139-161.

Evans, M.D.R., (1987). 'Language Skill, Language Usage and Opportunity: Immigrants in the Australian Labour Market', Sociology, 21, 253-274.

Miller, P.W., Mulvey, C., and Martin, N., (1995). 'What do Twins Studies Reveal about the Economic Returns to Education? A Comparison of Australian and US Findings', American Economic Review, 85, 586-599.

Mincer, J., (1974). Schooling, Experience and Earnings, National Bureau of Economic Research, Cambridge.

Nickell, S., (1982). 'The Determinants of Occupational Success in Britain', Review of Economic Studies, 49, 43-53.

Sicherman, N. and Galor, O., (1990). 'A Theory of Career Mobility' Journal of Political Economy, Vol. 98, 169-192. 


\section{APPENDIX A}

Table A1

Census Occupation Classification, Australia, 2001

\begin{tabular}{|c|c|}
\hline Census Code & Occupation $^{\mathrm{a}}$ \\
\hline 1 & Managers and Administrators n.f.d. \\
\hline 2 & Generalist Managers \\
\hline 3 & Specialist Managers \\
\hline 4 & Farmers and Farm Manangers \\
\hline 5 & Professionals n.f.d. \\
\hline 6 & Science, Building and Engineering Professionals \\
\hline 7 & Business and Information Professionals \\
\hline 8 & Health Professionals \\
\hline 9 & Education Professionals \\
\hline 10 & Social, Arts and Miscellaneous Professionals \\
\hline 11 & Associate Professionals n.f.d. \\
\hline 12 & Science, Engineering and Related Associate Professionals \\
\hline 13 & Business and Administrative Associate Professionals \\
\hline 14 & Managing Supervisors (Sales and Service) \\
\hline 15 & Health and Welfare Associate Professionals \\
\hline 16 & Other Associate Professionals \\
\hline 17 & Tradespersons and Related Workers n.f.d. \\
\hline 18 & Mechanical and Fabrication Engineering Tradespersons \\
\hline 19 & Automative Tradespersons \\
\hline 20 & Electrical and Electronics Tradespersons \\
\hline 21 & Construction Tradespersons \\
\hline 22 & Food Tradespersons \\
\hline 23 & Skilled Agricultural and Horticultural Workers \\
\hline 24 & Other Tradespersons and Related Workers \\
\hline 25 & Advanced Clerical and Services Workers n.f.d. \\
\hline 26 & Secretaries and Personal Assistants \\
\hline 27 & Other Advanced Clerical and Services Workers \\
\hline 28 & Intermediate Clerical, Sales and Services Workers n.f.d. \\
\hline 29 & Intermediate Clerical Workers \\
\hline 30 & Intermediate Sales and Related Workers \\
\hline 31 & Intermediate Services Workers \\
\hline 32 & Intermediate Production and Transport Workers n.f.d. \\
\hline 33 & Intermediate Plant Operators \\
\hline 34 & Intermediate Machine Operators \\
\hline 35 & Road and Rail Transport Drivers \\
\hline 36 & Other Intermediate Production and Transport Workers \\
\hline 37 & Elementary Clerical, Sales and Services Workers n.f.d. \\
\hline 38 & Elementary Clerks \\
\hline 39 & Elementary Sales Workers \\
\hline 40 & Elementary Services Workers \\
\hline
\end{tabular}


Table A1 (continued)

$41 \quad$ Labourers and Related Workers n.f.d.

$42 \quad$ Cleaners

$43 \quad$ Factory Labourers

$44 \quad$ Other Labourers and Related Workers n.f.d.

The Major Group Occupations are aggregates of these codes:

Managers and Administrators

(codes 1-4)

Professionals

(codes 5-10)

Associate Professionals

(codes 11-16)

Tradespersons

(codes 17-24)

Advanced Clerical

(codes 25-27)

Intermediate Clerical

(codes 28-31)

Production Workers

(codes 32-36)

Elementary Clerical

(codes 37-40)

Labourers

(codes 41-44)

${ }^{a}$ n.f.d.= Not further defined 


\section{APPENDIX B DEFINITIONS OF VARIABLES}

The variables used in the statistical analysis of the 2001 Australian Census of Population and Housing are defined below. The analyses are restricted to male full-time workers (i.e., working 35 hours or more per week) aged 20-64 years.

\begin{tabular}{|c|c|}
\hline Dependent Variables & \\
\hline Log of Hourly Earnings & $\begin{array}{l}\text { Natural logarithm of hourly earnings (where earnings are } \\
\text { defined as gross earnings from all sources). As weekly } \\
\text { earnings was coded in intervals, midpoints of intervals were } \\
\text { used to construct a continuous measure. The open-ended upper } \\
\text { category was assigned a value of } 1.5 \text { times the lower threshold } \\
\text { level. Weekly hours were recorded in intervals so midpoints } \\
\text { were used to construct a continuous measure. Hourly earnings } \\
\text { was then constructed by dividing weekly earnings by weekly } \\
\text { hours worked. }\end{array}$ \\
\hline
\end{tabular}

\section{Explanatory Variables}

Years of Education

Experience

Marital Status

English Proficiency

Government

Employment
This is a continuous variable that records the equivalent years of full-time education completed by the individual. Individuals holding a Postgraduate degree are assigned 19 years of education, Graduate Diploma and Graduate Certificate holders are assumed to have 17 years, Bachelor degree holders have the equivalent of 15.5 years of education, advanced Diploma and Diploma holders are coded as having 14 years, holders of Certificate are assigned 13 years, those who have completed either Year 9 or any years through to Year 12 are coded as 9, 10, 11 and 12 years of education, respectively, and those who did not go to school or attained Year 8 or below are assumed to have 7 years of education.

The experience variable was derived using the Mincer (1974) Proxy; Age - Years of Education - 5.

Binary variable set to one if an individual is married and set to zero otherwise.

Five English skills categories are distinguished: (i) speaks only English at home; speaks a language other than English at home and speaks English (ii) very well; (iii) well; (iv) not well; (v) not at all. In the analyses for immigrants from nonEnglish-speaking countries, dichotomous variables are included in the estimating equation for the latter four variables, with the "speaks only English at home" group being the benchmark group.

This is a binary variable that distinguish between those working in government organisations and those working in the 
private sector.

Birthplace of Individual Individuals who were born overseas (OSENG for overseas born from English-speaking developed countries; OSNENG for overseas born from all other countries) are distinguished from the Australian born.

Duration of Residence in Australia

This records the number of years an individual born overseas has lived in Australia. Three dummy variables were created based on the limited Census information: Arrived 1991-1995, Arrived 1986-1990, Arrived before 1986. The benchmark group is those who arrived after 1996-2001. 
Table B1

Descriptive Statistics of Variables by Birthplace Groups, Adult, Full-time Employed Males, Australia, 2001

\begin{tabular}{lcc}
\hline Variable & Mean & Standard Dev \\
\hline Australian Born: & & \\
Log Hourly Earnings & 2.882 & 0.562 \\
Years of Education & 12.072 & 2.396 \\
Years of Experience & 21.761 & 11.505 \\
Marital Status (Married = 1) & 0.708 & 0.455 \\
Government Sector & 0.164 & 0.371 \\
Occupation & & \\
$\quad$ Managers and Administrators & 0.144 & 0.351 \\
$\quad$ Professionals & 0.174 & 0.379 \\
$\quad$ Associate Professionals & 0.134 & 0.341 \\
$\quad$ Tradespersons & 0.213 & 0.409 \\
$\quad$ Advanced Clerical & 0.008 & 0.087 \\
Intermediate Clerical & 0.092 & 0.289 \\
Production Workers & 0.125 & 0.331 \\
Elementary Clerical & 0.039 & 0.194 \\
Labourers & 0.071 & 0.256
\end{tabular}

English-Speaking Developed Countries:

$\begin{array}{lcc}\text { Log Hourly Earnings } & 3.004 & 0.542 \\ \text { Years of Education } & 12.594 & 2.495 \\ \text { Years of Experience (EXPER) } & 25.430 & 10.753 \\ \text { Years of Arrival: } & & \\ \quad \text { Arrived 2000-2001 } & 0.046 & 0.210 \\ \text { Arrived 1998-1999 } & 0.056 & 0.230 \\ \text { Arrived 1996-1997 } & 0.043 & 0.203 \\ \text { Arrived 1991-1995 } & 0.068 & 0.253 \\ \text { Arrived 1986-1990 } & 0.125 & 0.331 \\ \quad \text { Arrived Before 1986 } & 0.661 & 0.473 \\ \text { Marital Status (Married =1) } & 0.790 & 0.407 \\ \text { Government Sector } & 0.151 & 0.358 \\ \text { Occupation } & & \\ \quad \text { Managers and Administrators } & 0.154 & 0.361 \\ \text { Professionals } & 0.216 & 0.412 \\ \text { Associate Professionals } & 0.130 & 0.336 \\ \text { Tradespersons } & 0.204 & 0.403 \\ \text { Advanced Clerical } & 0.007 & 0.082 \\ \text { Intermediate Clerical } & 0.090 & 0.286 \\ \text { Production Workers } & 0.105 & 0.307 \\ \text { Elementary Clerical } & 0.037 & 0.188 \\ \text { Labourers } & 0.058 & 0.233\end{array}$




\begin{tabular}{lcc}
\hline Non-English-Speaking Countries: & & \\
Log Hourly Earnings & 2.883 & 0.562 \\
Years of Education & 12.673 & 3.067 \\
Years of Experience (EXPER) & 25.067 & 11.467 \\
English Proficiency: & & \\
$\quad$ Very Well & 0.408 & 0.491 \\
$\quad$ Well & 0.231 & 0.421 \\
$\quad$ Not Well & 0.072 & 0.258 \\
$\quad$ Not at All & 0.004 & 0.061 \\
Years of Arrival: & & \\
Arrived 2000-2001 & 0.028 & 0.165 \\
$\quad$ Arrived 1998-1999 & 0.039 & 0.193 \\
Arrived 1996-1997 & 0.037 & 0.190 \\
Arrived 1991-1995 & 0.107 & 0.310 \\
$\quad$ Arrived 1986-1990 & 0.183 & 0.387 \\
Arrived Before 1986 & 0.606 & 0.489 \\
Marital Status (Married 1$)$ & 0.780 & 0.414 \\
Government Sector & 0.124 & 0.330 \\
Occupation & & \\
$\quad$ Managers and Administrators & 0.112 & 0.315 \\
Professionals & 0.218 & 0.413 \\
Associate Professionals & 0.129 & 0.336 \\
Tradespersons & 0.180 & 0.384 \\
Advanced Clerical & 0.007 & 0.083 \\
Intermediate Clerical & 0.067 & 0.250 \\
Production Workers & 0.148 & 0.355 \\
Elementary Clerical & 0.035 & 0.185 \\
Labourers & 0.104 & 0.305 \\
\hline
\end{tabular}

